\begin{tabular}{|c|ccc|}
\hline \multicolumn{4}{|c|}{ ADIYAMAN ÜNIVERSITESI SOSYAL BILIMLER ENSTITÜSÜ DERGISI } \\
ISSN: 1308-9196 \\
\cline { 2 - 4 }
\end{tabular}

\title{
CEP TELEFONUYLA İNGİLIZCE KELİME ÖĞRENME: MESAJINIZ VAR
}

Yıldız TURGUT*

Özet

Bu çalışma, mobil teknolojisinin bir parçası olan SMS'in ingilizce kelime öğrenimindeki yerini araştırmaktadır. Türkiye'de yapılan bu çalışma bir devlet üniversitesindeki gelir seviyesi düşük 60 öğrenci ile bir hafta boyunca yürütüldü. Her biri Ingiliz Dili Eğitimi Hazırlık programına devam eden 30 öğrenciyi kapsayan kontrol ve deney grupları oluşturuldu. Kontrol grubunun klasik yöntemlerle yeni kelimeler öğrenmesi beklenirken, deney grubuna yeni kelimeler kısa SMS'lerle gönderildi. Nicel ve nitel olarak yapılan verilerin analizi, deney grubunda anlamlı bir fark olduğunu göstermektedir. Bulgular, SMS'in sayısal vatandaş olarak adlandırılan öğrencilere kelime öğreniminde motivasyon sağladığı, itme etkisi (push) ile düzenli çalışmaya teşvik ettiği ve ingilizce kelime öğretiminde kullanılabileceğini göstermektedir.

Anahtar Kelimeler: mobil öğrenme, cep telefonu, SMS, kelime öğrenme, Ingilizce dili öğretimi

\section{LEARNING VOCABULARY VIA CELLPHONES: YOU HAVE AN SMS}

\begin{abstract}
This study investigates the use of SMS - a part of Mobile Technology-as a potential of learning vocabulary in English. The study was carried out for a week with 60 students from low SES in Turkey. A control and an experimental group -each consisting of 30 prep class students attending to ELT department at a university- were formed. While the control group was expected to learn the new words by classical techniques, the same words were sent to the experimental group as short messages. Both quantitative data analysis and qualitative survey data show that at the end of the study, there is a significant difference in favor of experimental group. Implications indicate that SMS can be used to teach vocabulary to digital natives providing motivation and promoting the regular study with push effect.
\end{abstract}

Key Words: m-learning, mobile phone, SMS, vocabulary learning, ELT

\section{INTRODUCTION}

Mobile learning -learning with mobile devices - is identified both by being available "anywhere, anytime" (Geddes 2004). M-learning can be defined as "any educational provision where the sole or dominant technologies are handheld or palmtop devices" (Traxler, 2005 p.261). These mobile devices are "...any device that is small, autonomous and unobtrusive enough to accompany us in every moment" (Trifanova et al. 2004 p.3). This definition may mean that mobile learning could include mobile phones, smartphones, MP3/MP4 players, personal digital assistants (PDAs) and their peripherals, perhaps tablet PCs and palmtop computers (Kukulska-Hulme \& Shield, 2007; Traxler 2005). The literature review considered the following options for m-learning: tablet PCs (Corlett \& Sharples, 2004), iPods (Duke University, 2004; Perlman, 2005), palmtop computers (Savill-Smith \& Kent, 2003), Personal Digital Assistants (PDAs) (Singh, Denoue, \& Das,

\footnotetext{
*Yrd. Doç. Dr., Mersin Üniversitesi Eğitim Fakültesi İngiliz Dili Eğitimi Bölümü, yildiztr@gmail.com
} 
2004; Squire, Johnson, Holland, Nataf, \& Klopfer, 2002; Cochrane, 2005), mobile phones and SMS (Wagner, 2005; Cheung, 2004; Faulkner, 2004; Gonzales, Ittelson, \& Krebs, 2004; Geddes, 2004; Mellow, 2005), and wireless infrastructure (Sotillo, 2003; Falk, 2003; Lu et al, 2003).

Among all devices, some (especially, mobile phones) have enjoyed extensive diffusion, whereas devices such as laptop computers have only recently reached the price point where they can reach critical mass for learners (Cobcroft et al, 2006). Due to availability, in the last five years, mobile phones have steadily assumed a place in further and higher education in the USA, the Far East/Pacific Rim and the UK (Garner et al, 2002), (Briggs \& Stone, 2002), (Alsop et al, 2002), supporting distance learners and part-time students. There has also been a growing understanding of mobile phones' potential for supporting learning (Attewell \& Savill-Smith, 2003) and of the evolution of cultural life and social behavior with the take up of mobile phones in many parts of the world (Plant, 2001).

Mobile phones have several application features. Among them SMS (Short Message Service) is the most reliable and popular message communication on mobile phones today (So, 2009). Reasons contributing to this popularity include low cost, asynchronous nature (users can reflect before sending and reply at their leisure) and potential for private/quiet use (Mitchell, Heppel, \& Kadirire, 2002). Of great popularity among young adults is messaging on mobile phones, by way of SMS (Godwin-Jones, 2005). Studies among student populations report on $80 \%$ of students sending SMS every day (Divitini et al, 2002; Markett, ArnedilloSanchez, Weber, \& Tangney, 2004; Markett, et al 2005). For many students today, mobile phones have become an important way to keep in touch with friends. (Kiernan \& Aizawa, 2004). In this regard, availability plays a key role. That is, students can access mobile phones much more easily than PCs. That is, mobile phones outnumber PCs 5 to 1 (Cohen, 2002). Meanwhile, mobile phones - the communication tool of choice of many of today's university and high school students - have received little attention even though they include many important functions normally associated with PCs such as e-mail, Internet access and even camera and video functions (Kiernan \& Aizawa, 2004). To date, instructors rarely ask students to use their mobile phones for schoolwork. In fact, many universities, including ours, explicitly prohibits the use of mobile phones in class. Not only are the melodies announcing a call a potential distraction, but learners have apparently been caught using text messaging functions to communicate with each other during class time, and even attempting to cheat during tests (Kiernan \& Aizawa, 2004). Yet, recently it has been increasingly observed that students are spontaneously using their mobile phones for various educational tasks. Especially, in foreign-language classes, some students look up words in bilingual dictionaries (either web-based or built into some phones). Other usages might include that students illustrate their oral presentation with snapshots, taken and displayed on their mobile phones, they documented the graphic programming exercises by using their mobile phone to photograph their PC screen. Additionally, several students regularly use the cameras in their mobile phones to photograph blackboards and PowerPoint displays. (Houser \& Thornton, 2005)

Currently, some research projects have investigated mobile phones and their use in education and some language teaching services have begun to use SMS in support of language learning. Among the m-learning 
projects underway are a Finnish language learning program (grammar and pronunciation) and Java-based review exercises from Great Britain (Godwin-Jones, 2005). The BBC World Service's English section has been using SMS in conjunction with radio broadcasts of English language programs in French-speaking West Africa. There is also a project underway using SMS to deliver English instruction in China (Godwin-Jones, 2005). In Europe, the EU has funded a major initiative called m-learning which uses mobile phones to reach young adults who have not done well in traditional learning environments (Godwin-Jones, 2005). The idea is that through the use of the ubiquitous mobile phone, one may be more likely to engage young learners in a time (of their choosing) and a place (away from formal institutional settings) more conducive to their learning preferences.

Mobile phones are relatively cheaper and since most students already carry phones, most classes are already equipped (Houser et al, 2002). The widespread use of mobile phones amongst the students leads to question how this technology might help to improve the students' English vocabulary learning and to examine their attitude towards receiving SMS in this learning process. The aim of this experimental study has been to investigate the potential of using mobile phones in teaching new English language words to prep year undergraduate students of English Language Teaching (ELT) department. In order to reach this aim, the following questions guided the study:

1. Is Mobile Technology-SMS- useful as a vocabulary learning tool?

2. What are the students' attitudes towards SMS during the vocabulary learning process?

Answering to such questions will shed light to pedagogical implications of teaching vocabulary in ELT via $\mathrm{m}$ learning at anywhere, anytime.

\section{PREVIOUS RESEARCH}

Learning a language involves learning in the domains of phonology, grammar, vocabulary and discourse (Levy \& Kennedy, 2005). There is growing evidence to suggest that particular technologies, through their design and functionality, lend themselves more to one or other of these domains or levels of language learning (Levy 1997, 2003). The evidence suggests that mobile phones have great potential in education (Traxler, 2005). To date, vocabulary learning has been a focus for developing applications and materials for the mobile phone (Kennedy \& Levy, 2008; Levy, 2009; Stockwell, 2007b; Thornton \& Houser, 2002). As one of the application, SMS technologies were proved by many researchers to be especially effective for language learning like vocabulary learning (Andrews 2003, Levy \& Kennedy 2005, McNicol 2005, Norbrook \& Scott 2003, Pincas 2004). The reasons are that discrete SMS messages can be provided in a short and succinct manner, and readily available for learners such as in commuter trains or buses (So, 2009). The learning process is not as interrupting or disturbing as other media like audio or video. An overview of mobile assisted language learning by Kukulska-Hulme and Shield (2007) also points out another advantage that learners are able to obtain the information anytime and anywhere themselves, the mobile devices are ideal for the "push" approach of learning by sending information to the learners at set times and on set 
days. As there are quite a number of SMS projects for teaching and learning were reported in the literature, only some studies especially focusing on vocabulary teaching are highlighted as follows.

Lu (2008) explored the application of SMS in second language learning in Taiwan. Similarly, SMS vocabulary lessons were sent to EFL learners and reported the students read their messages literally anytime, everywhere - in commuting, between classes, or even before going to bed. Students preferred to learn through mobile phones than PCs, because mobile phones were more convenient than PCs in this situation. Like Lu, Dias' (2002b) findings showed the similar preference. In his survey study, when students were asked would they study/practice English using their cell phones, if they knew a way to do it, 57.9 per cent of girls replied positively and 47.4 per cent of the boys replied favorably too.

Thornton and Houser (2001, 2005) investigated the educational use of mobile phone email at Japanese universities, where spaced (repeated, interval) practice of foreign language vocabulary is difficult to facilitate, since classes meet only once a week. Thornton and Houser (2001) used SMS and email to send 100-word English vocabulary lessons at 9:00, 12:30, and 17:00 to the mobile phones of 44 Japanese university students enrolled in two EFL classes, hoping to promote regular study. They introduced five words each week to students and sent short mini lessons three times a day via SMS messages. Individual lessons include learning a single word, some facet of a word, examples or reviews, of previously learned words. Pre- and post-tests determined the number of words learned during each two-week cycle of crossover study. Compared with students urged to regularly study identical materials on paper or web, students receiving mobile email learned more $(p<0.05)$. Most subjects preferred receiving these lessons on mobile phones rather than PCs, and almost all felt this a valuable teaching method. Despite limited success in controlling the time of review during the day, the mobile push method was successful at promoting daily study and resulted in more effective learning. In the following study Thornton and Houser (2005) examined whether mobile-based email has been used to promote vocabulary learning or not. Similar to the previous study's findings, the later one also showed that students have also been encouraged to use mobile phones to access web-based video clips explaining English idioms.

Levy and Kennedy (2005) exploited teaching Italian vocabulary via SMS. The study builds upon the initiatives of Houser et al. (2001) and Dias (2002a, 2002b) on vocabulary learning, and applies these ideas to the learning of Italian within an Australian university context. Students were sent new words, definitions, and example context sentences to their mobile phones so that they could learn in between the lessons and tutorials of the course. The vast majority of students enjoyed receiving the messages $(17 / 18=94.4$ percent). The important finding that emerged from the survey findings and the focus group was the 'knockon' effect of the SMS messages that were sent. That a message may trigger the receiver to actively engage in language learning between classes is enormously beneficial, especially for vocabulary learning. Similar reports by the same authors on the topic can be found (Kennedy \& Levy, 2008).

Çavuş and İbrahim (2009) reported an experiment in using SMS to support learning of technical English words. Spaced repetitions of the same messages were sent on different days through a SMS-based system called mobile learning tool (SMS) developed by the authors. The pre- and post-tests were administered to 
45 1st-year undergraduate students. The findings showed that participants motivated and learned new words with the help of their mobile phones. The participants stated that using the SMS system as an educational tool was beneficial for them.

So (2009) also examined a project of using SMS technology. He provided the possible underlying technologies to implement such the teaching and learning systems. In this study, the underlying technology of using GSM modems to build the SMS-based teaching and learning system was revealed. The system is capable of supporting administrative, teaching and learning activities via the SMS technology. So reported that the cost of the system as a limitation, but he suggested to bulk purchases of SMS services from mobile carriers as a solution.

The mobile language learning system, designed in Finland (Kadyte, 2004) delivers lessons using sound and text to teach grammar and vocabulary. It tracks the learner's progress and integrates voice technology for user interaction. Evaluation showed a positive response from learners and indicates that the use of mobile devices can significantly increase student motivation and interest.

Referring to the previous studies in the field of teaching vocabulary via SMS (example, Thornton \& Houser, 2005 and Levy \& Kennedy, 2005), few current literature argue that SMS teaching includes its limited features such as small screens, small memory and storage capacity in mobile phones, limited characters to be sent or received, (Shudong \& Higgins, 2006) the private link that mobile phones give students (Market et al, 2005) and lack of students' engagement (Fotouhi-Ghazvini et al, 2009). Therefore, many people would lack the psychological motivation needed to use mobile phone learning consistently (Shudong \& Higgins, 2005) and it may not be possible to keep students motivated.

The evidences so far suggest that mobile SMS technology might prove especially effective for vocabulary learning despite some controversial arguments and limitations. Vocabulary items can be presented through relatively short, discrete definitions and examples that suit the screen dimensions and general handling capabilities of a mobile phone.

\section{METHODOLOGY}

\section{Theoretical Framework}

The mobile learning evaluation framework structures the evaluation planning around general goals for assessing usability, educational effectiveness, and overall impact (Sharples et al, 2006 p. 16). More specifically, it comprises three levels: Micro level, Meso level and Macro level (Sharples et al, 2006). In this present study SMS usage is considered as a micro level in mobile learning. That is, the present study examined the individual activities of the technology users so as to identify issues of usability and assess how effective, efficient and satisfying is the user's experience of carrying out the individual activities supported by the technology. 
As a learning theory the most relevant to m-learning, informal learning, has been chosen as learning can happen anywhere and anytime (Geddes, 2004). Based on this theoretical framework, language learning materials for use with mobile device were appropriately designed and aimed to make use of the "highly fragmented" attention of m-learners by providing "short (from 30 seconds to 10 minutes) learning modules" (Trivanova \&Ronchetti, 2003; Kukulska-Hulme \& Shield, 2007). In accordance with this, SMS technology was employed according to a push system (Mellow, 2005; Levy \& Kennedy, 2005) where new vocabulary messages were sent to all participants in a course.

\section{The Participants}

This experimental study was carried out with a total of 60 volunteer students from Preparatory classes in English Language Teaching (ELT) Department of a Turkish State University during the fall semester of 2009. The students attending to these prep classes were with lower socio-economic status and their English language proficiency level was intermediate as they were not able to pass the English language proficiency exam at the beginning of the fall semester. All of the participants were randomly selected and willing to participate in the experiment. Before the study, two points were checked: whether the participants had mobile phones or not, and whether the participants had access to them all the time or not. The model and the features of mobile phones used were not important in this experiment because any mobile phone can receive and display SMS messages.

\section{Data Collection}

Data were collected through pre-and post-tests and a written survey. Participants were divided into two groups as a control and an experimental group each consisting of 30 students. During the study a pre- and post-test were administered to the participants to find out the learning abilities of students. In both tests, the meanings of the words used in the experiment were asked. The test conditions (e.g., the duration of the test and the environment) were identical in both tests. With the use of the pre-test (see Appendix A) both the knowledge of the words used in the study was defined and 10 common unknown words were chosen among 20 words to be used as post-test after a week.

When asked to the students in the control group what kinds of techniques they used for learning new words, they indicated that they memorized words by hearth, they wrote the new words for several times and they grouped the words. These techniques can be called as the classical techniques for vocabulary learning since they are based on memorization through rehearsal and encoding. For the present study, Turkish meanings of the words were given to the control group at the beginning of the week and they were told to learn the words with their own classical techniques. On the other hand, the experimental group was divided randomly into three groups $-\mathrm{A}, \mathrm{B}$ and $\mathrm{C}$ - to be provided to take the messages equally. The words were arranged in two separate messages so that the recipients could read these messages on their small screens without having to scroll down many times. Each recipient had the messages for three times in a day and 90 messages (45 the first five words, 45 the second five words) were sent to each group daily. Hence, 
the purpose was to activate the unknown words through using them in different context via SMS. Thus, the experiment was completed in six days. The messages were sent in the following sequence:

Group A: days 1,2 and 5;

Group B: days 2,3 and 6;

Group C: days 3,4 and 6.

Spaced repetition of words via SMS was employed in this present study because research shows that spaced repetition in vocabulary learning results in "more robust learning than massed repetition" (Nation 2001: 76). In other words, repetitions undertaken across a period, usually at ever-increasing intervals, are a more effective way to learn and retain new words than sustained repetition during a single, continuous period. SMS messages sent at intervals via a mobile phone have the potential to meet this requirement rather well. A post-test (see Appendix B) was applied to the participants to compare the scores after they had the messages during the week and to examine whether the SMS technique would be effective or not.

The participants were asked to fill out a written survey at the end of the experiment in order to receive their feedback on the use of the SMS system. The survey, adapted by Çavuş and Ibrahim (2009), was applied to the experimental group by asking the students to fill the survey questionnaire which was phrased to determine whether or not there was a positive response to the SMS system. The questionnaire (see Appendix C) was formed in 5-point Likert scale type questions, consisting of 15 items, with 5 being a response of strongly agree and 1 representing strongly disagree. Each question was phrased so that strongly agree represented a positive reaction to the project.

\section{FINDINGS and DISCUSSION}

\section{Using SMS in Vocabulary Learning}

At the beginning of the week, the pre-test results showed that the students in both groups knew at most two or three words among 20 words. However, in order to form equal conditions for each group, 10 common unknown words were chosen and used in the experiment process for both of the groups. In that point, it should be emphasized that the pre-test used in this study had a different aim and the results of the groups for the pre-test were considered as zero. Thus, it was regarded just post-test results were taken into account for the two groups.

When the experimental part of the study was carried out and was over within a week, the success of both the control group and the experimental group in the knowledge of the new words in English language was defined with the results of the pre-test and post-test. To examine whether there is any significant difference between the control and the experimental groups in terms of their success in vocabulary learning after the experiment, Independent Samples t-test was applied to the data.

Table 1 shows the groups' statistics of vocabulary learning performance and it indicates that there is a significant difference $(t=10,77$ and $p<0,05)$ between the two groups in favor of the experimental group. 
Table 1. Participants' success of vocabulary learning

\begin{tabular}{|l|l|l|l|l|l|l|}
\hline & GROUP & N & Mean & SD & Sig.(2-tailed) & t \\
\hline POSTTEST & Experimental group & 30 & 8,7667 & 1,77499 & & \multirow{2}{*}{ 10,770 } \\
\cline { 1 - 6 } & Control group & 30 & 2,9667 & 2,35597 &, 000 & \\
\hline
\end{tabular}

While the mean for the control group is 2,9667 , it is 8,7667 for the experimental group which means the success of vocabulary learning via classical techniques scores quiet lower than the learning success of new words in English with the support of SMS.

\section{The Participants' Attitudes Toward SMS}

Knowing about the attitudes of the experimental group to the SMS also forms the backbone of the study since such a qualitative study based on the use of SMS in vocabulary learning have not been carried out with the university students before especially with the underprivileged ones.

Table 2 shows the mean scores of answers to the questionnaire and it can be clearly seen that most of the ratings are over 4 . It reveals that the participants have positive attitude towards SMS. The mean ratings also give the idea the participants are mostly agree with facing the SMS in their education. The mean rating of item 14, "I would like to see the SMS system to be used in next semesters as well", supports this generalization, too. Table 2 indicates that items 6 and 15 have the highest score together with 14. Related to the second research question, the participants found learning new words with SMS technique very effective. They also stated that they found this system enjoyable and they were motivated in the items 1 and 8.

Table 2. The Mean Ratings of Each Item

\begin{tabular}{|l|l|}
\hline Survey items (N =15) & Mean \\
\hline 1. I found the SMS system enjoyable. & 4.3 \\
\hline 2. I think all my friends who used the SMS system are happy about it & 3.8 \\
\hline 3. I can easily remember the words that I received on my mobile phone. & 4.3 \\
\hline 4. The words I learned with the SMS system have increased my vocabulary. & 4.3 \\
\hline 5. I would like a similar system to be used in all of my other lessons & 3.9 \\
\hline 6. With the help of SMS system I learned new words. & 4.5 \\
\hline 7. SMS system helped me correct the meanings of words I knew wrongly. & 3.7 \\
\hline 8. Using the current technology with the SMS system has motivated me & 4.2 \\
\hline 9. Using a new novel teaching tool has motivated me. & 4.3 \\
\hline 10. Because I am much occupied during class hours it is more difficult to learn new words. But I & 4.2 \\
\hline
\end{tabular}




\begin{tabular}{|l|l|}
\hline can learn and remember new words easier during my leisure time. & \\
\hline $\begin{array}{l}\text { 11. It would be nice if the SMS system supported 'searching' where I could search for a new word. } \\
\text { 12. It would have been more effective if we could use two-way communication with the SMS } \\
\text { system. }\end{array}$ & 3.8 \\
\hline $\begin{array}{l}\text { 13. I preferred the messages to come as multimedia messages. } \\
\text { 14. I would like to see the SMS system to be used in next semesters as well. }\end{array}$ & 3.2 \\
\hline 15. I found learning new words with the SMS system very effective. & 4.5 \\
\hline Mean (15 questions) & 4.5 \\
\hline
\end{tabular}

The item 13 has the lowest score and according to Table 2, not all of the participants have preferred the messages to take as multimedia messages which might be due to some of the participants' purposes of using mobile phones and the models. Most of the students use their phones for common purposes, such as sending and receiving messages, taking photos and calling someone, which proceeds the idea that users did not adequately explore functions of cell phones and this leads to a great waste of mobile resources (Cui \& Wang, 2008). In addition, some of the students did not have high tech mobile phones and they have to use their phones with limited functions.

\section{IMPLICATIONS and FUTURE RESEARCH}

In this present study, the statistical data had similar pattern with previous studies (Levy \& Kennedy, 2005; Thornton \& Houser, 2001, 2005) showing that push effect of SMS is beneficial for vocabulary learning. Also, the results of the questionnaire indicate that participants really benefited from the SMS and the common idea was that participants reacted positively receiving SMS and they wanted to use this technology in their learning environment in contrast to the studies of Shudong and Higgings (2006) who argued that SMS is a new technology that should be improved; therefore, it is early to determine its effectiveness. Moreover, unlike the findings of Fotouhi-Ghazvini et al, (2009) which indicate that SMS are lack of students' engagement with less psychological motivation for learning, the present study has similar findings with previous studies (Dias 2002a,b; Kadyte, 2004; Levy \& Kennedy, 2005, 2008; Lu, 2008; Thornton \& Houser, 2005; Çavuş \& Ibrahim, 2007) motivating students with increased engagement, mobile technologies and infrastructure facilitate this revolution of 'always-on learning, accessible to the masses, but tailored to the individual' (Thomas, 2005, p. 5).

Thornton and Houser (2005) reported receiving few complaints about the mobile phone's tiny screen. Unlike them, the participants in this present study did not complain about it. Nevertheless, only one student pointed out a problem with respect to understanding a character in the message which was caused by the function of her mobile phone. 
In terms of the cost to send and receive SMS messages during vocabulary teaching process unlike Market, et al's (2005) and So (2009), in this present study it was not reported as a problem since the participants were not expected to respond the messages and the researcher benefited from the free charge of message provided by the GSM company.

The interconnectedness between in-class and out-of-class activity only occurs successfully when the mobile phone messages are very carefully integrated into the content and goals of the wider scheme of work (Kukulska- Hulme \& Traxler, 2005). In that, teachers should be aware of the pedagogical purpose, as reported by previous studies as well as this present study, mobile SMS technology fits vocabulary learning presenting an example for teaching.

The present study shows the effectiveness of vocabulary teaching via SMS, language teachers can plan recycling of new terms and to prepare messages in advance for delivery later at specific times. Thus, messages can be distributed at the time they are required to complement face-to-face work in class and the curriculum (Levy, 2009).

Powerful features and functions of mobile devices offer mobile phone users such as teachers and instructional designers great potential and feasibility for educational use, especially in the mobile learning, which will give people from diverse fields a new way to learn. Due to the fact that mobile phones with Internet access have not been available by many students yet, the study was carried out with text-based messages. Since not all of the models of mobile phones used by the participants were being supported with picture or figure, only text-based SMS messages including the words and their meanings in native language (Turkish) were sent to the participants. With recent innovations such as the iPhone including Internet access, voice messaging, short message service (SMS) text messaging, photography, and video recording, the future work might investigate $3 \mathrm{G}$ system developing in Turkey. Thus, future works may focus on a broader context taking the Internet accessible phones into account such as supporting the word learning process with videos, graphics, pictures, voice or games on the Internet via mobile phones. Also, they may add the pronunciation of the target words on messages as well.

Moreover, Internet access might add new perspective to the future study investigating two dimensions (meso and macro levels- Sharples et al, 2006; and pull and interactive systems-Mellow, 2005), rather than micro level and push systems as presented in this present study. That is, the participants may also response to the messages directly or take part in the learning process on the Internet interacting with their peers.

Other form of informal learning, game-based learning, can be considered as a particular form of incidental learning where the learner is engaged in an activity that may not be directly tied to the task at hand (Fotouhi-Ghazvini et al, 2009). Vocabulary learning and SMS technology might be integrated as Goh and Hooper's (2007) example of SMS crossword puzzle system in a classroom environment and as a further step students' vocabulary learning might be investigated as an out of school context as conducted in this present study. 


\section{CONCLUSION}

In general mobile phones proved to be popular learning tools with the learners involved in this present study. This present study employed SMS combining of features in mobile devices - portability, connectivity, and low cost - makes them valuable educational tools (Houser et al, 2002). Mobile learning potentially brings the rewards of placing institutions at the forefront of pedagogical practice and addresses student requirements for flexibility and ubiquity, that is, 'anywhere, anytime, and any device' learner engagement especially for underprivileged students.

This study focused on how the use of SMS - a crucial part of Mobile Learning- affects the potential of learning vocabulary in English. As the results showed, there is a significant difference in favor of the experimental group to whom the new words were sent via SMS messages. Taken together, the results of the post-test and the attitudes of the digital natives towards SMS demonstrate a positive picture promoting regular study.

\section{ACKNOWLEDGEMENT}

I would like to thank to Prof. Dr. Adnan Erkuş, Fahriye Süslü and Nevin Şemli for their supports for their help while conducting and analyzing the data.

\section{REFERENCES}

Alsop, G., Briggs, J., Stone, A., \& Tompsett, C. (2002), “M-learning as a Means of Supporting Learners: Tomorrow's Technologies Are Already Here, How Can We Most Effectively Use Them in The E-learning Age?", Networked Learning 2002, Proceedings of the Third International Conference on e-Learning in Higher Education and Lifelong Learning, March 2002, Sheffield, USA.

Andrews, R. (2003). "Lrn Welsh by txt msg", BBC News World Edition. Retrieved August 15, 2009, from: http://news.bbc.co.uk/2/hi/uk_news/wales/2798701.stm

Attewell, J., \& Savill-Smith, C. (2003). Young People, Mobile Phones and Learning. London: Learning and Skills Development Agency.

Briggs, J. \& Stone, A. (2002). "ITZ GD 2 TXT - How To Use SMS Effectively in M-Learning", European Workshop on Mobile and Contextual Learning, 20-21 June, Birmingham, U.K.

Cheung, S. (2004). Using mobile phone messaging as a response medium in classroom experiments, Social Science Research Network, Retrieved December 13, 2009, from http://papers.ssrn.com/sol3/papers.cfm?abstract_id=605863.

Cobcroft, C., Towers, S., Smith, J. \& Burns, A. (2006). Literature Review into Mobile Learning in the University Context. Retrieved September 25, 2008, from http://eprints.qut.edu.au/archive/00004805/01/4805.pdf

Cochrane, T. (2005), “Mobilizing Learning: A Primer for Utilizing Wireless Palm Devices to Facilitate a Collaborative Learning Environment", Proceedings of ASCILITE 2005. Retrieved 
December 10, 2010, from

http://www.ascilite.org.au/conferences/brisbane05/proceedings.shtml.

Cohen, A. (2002). “Japan Loves Wireless” PC Magazine, 21-18, (136).

Corlett, D., \& Sharples, M. (2004), “Tablet Technology for Informal Collaboration in Higher Education", Proceedings of MLEARN 2004: Mobile Learning Anytime Everywhere, London, UK.

Cui G. \& Wang, W. (2008). “Adopting Cell Phones in EFL Teaching and Learning” Journal of Educational Technology Development and Exchange, 1-1, (69-80).

Çavuş, N. \& Ibrahim, D. (2009). “M-Learning: An Experiment in Using SMS to Support

Learning New English Language Words" British Journal of Educational Technology, 40-1, (7891).

Dias, J. (2002a). “Cell Phones in the Classroom: Boon or Bane?” Calling Japan, 10-2, (16-22).

Dias, J. (2002b). “Cell Phones in the Classroom: Boon or Bane?” [Part 2] Calling Japan, 10-3, (814).

Divitini, M., Haugalokken, O. K., \& Norevik, P.A. (2002), “Improving Communication Through Mobile Technologies: Which Possibilities?", IEEE International Workshop on Wireless and Mobile Technologies in Education, Växjö, Sweden.

Duke. (2004). iPods Enter Duke Classes. Retrieved December 13, 2010, from

http://cit.duke.edu/ideas/newprofiles/ipod_faculty_articles.do.

Falk, H. (2003). “Electronic Campus” The Electronic Library, 21-1, (63-66).

Faulkner, S. (2004). “Have You Got My Number?” Campus Review, August 18-24, (17-19).

Fotouhi-Ghazvini, F.,Earnshaw, R., Robison, D. \& Excell, P. (2009). “The MOBO City: A Mobile Game Package for Technical Language Learning" IJIM, 3-2, (19-24).

Garner, I., Francis,J., \& Wales, K. (2002). “An Evaluation of an Implementation of a Short Message System (SMS) to Support Undergraduate Student Learning", Mlearn 2002, Proceedings of the European Workshop on Mobile and Contextual Learning, June 2002, Birmingham, UK.

Geddes, S. (2004). "Mobile Learning in the 21st Century: Benefit for Learners" The Knowledge Tree, 6. Retrieved December 13, 2009, from

http://flexiblelearning.net.au/knowledgetree/edition06/html/pra_simon_geddes.html.

Godwin-Jones, R. (2005). “Emerging Technology Messaging, Gaming, Peer-to-peer Sharing: Language Learning Strategies \& Tools for the Millennial Generation” Language Learning \& Technology, 9-1, (17-22). 
Goh, T., \& Hooper, V. (2007). “To TxT or not to TxT: That's the Puzzle" Journal of Information Technology Education, 6, (441-453).

Gonzales, G., Ilttelson, J., \& Krebs, A. (2004). “Mobile Education: On Campus and in the Community", Proceedings from EDUCAUSE 2004, Denver, CO.

Houser, C. \& Thornton, P. (2005). Poodle: A Course Management System for Mobile Phones, (211-215), Proceedings of the 2005 IEEE International Workshop on Wireless and Mobile Technologies in Education (WMTE'05), IEEE Computer Society Press.

Houser, C., Thornton, P. \& Kluge, D. (2002). “Mobile Learning: Cell Phones and PDAs for Education", JALTCALL, 18-19 May 2002. Hiroshima Jogakuin University, Hiroshima, Japan.

Houser, C., Thornton, P., Yokoi, S. and Yasuda, T. (2001), Learning on the Move: Vocabulary Study via Mobile Phone e-mail, (1896-1897), (Ed: C. Montgomerie \& J. Viteli),

Proceedings of World Conference on Educational Multimedia, Hypermedia and Telecommunications 2001, Chesapeake, VA: AACE.

Kadyte, V. (2004). Learning Can Happen Anywhere: A Mobile System for Language Learning, (73-78), (Ed: J. Attwell \& C. Savill-Smith), Learning with Mobile Devices, London: Learning and Skills Development Agency.

Kennedy, C., \& Levy, M. (2008). “L'italiano al Telefonino: Using SMS to Support Beginners' Language Learning" ReCALL Journal, 20-2, (141-161).

Kiernan, P. \& Aizawa, K. (2004). “Cell Phone in Task Based Learning: Are Cell Phones Useful in Language Learning Tools?" ReCALL Journal, 16-1, (71-84).

Kukulska-Hulme, A., \& Shield, L. (2007). An Overview of Mobile Assisted Language Learning: Can Mobile Devices Support Collaborative Practices in Speaking and Listening? Retrieved May 15 2010, from The Open University, UK: portal.acm.org/citation.cfm?id=1520087

Levy, M. (1997). Computer-assisted Language Learning: Context and Conceptualization. Oxford: Oxford University Press.

Levy, M. (2003). Effectiveness of CALL technologies: finding the right balance, (1-18),(Ed: R. Donaldson \& M. Haggstrom), Changing Language Education Through CALL, Lisse: Swets and Zeitlinger.

Levy, M. (2009). "Technology in Use for Second Language Learning" The Modern Language Journal, 93, (769-782).

Levy, M. \& Kennedy, C. (2005). Learning Italian via Mobile SMS, (76-83), (Ed:A. Kukulska-Hulme and J. Traxler), Mobile Learning: A Handbook for Educators and Trainers, London: Taylor and Francis. 
Lu, M. (2008). "Effectiveness of Vocabulary Learning via Mobile Phone" Journal of Computer Assisted Learning, 24, (515-525).

Lu, J., Chun-Sheng, Y., Chang, L., \& Yao, J.E. (2003). "Technology acceptance model for wireless internet" Internet Research: Electronic Networking Applications and Policy, 13-13, (206-222).

Market, C., Sánchez, A., Weber, S., \& Tangney, B. (2004). "PLS Turn UR Mobile On”: Short Message Service (SMS) Supporting Interactivity in the Classroom, (491-494), (Ed: Kinshuk, Demetrios G. Sampson and Pedro Isaias), Proceeding of the Cognition and Exploratory Learning in Digital Age, Lisbon: International Association for Development of the Information Society.

Market, C., Sánchez, A., Weber, S., \& Tangney, B. (2005). “Using Short Message Service (SMS) to Encourage Interactivity in the Classroom" Computers \& Education, 46-3, (280-293).

McNicol, T. (2005). "Language E-learning on the move”, Japan Media Review.

Retrieved August 1, 2008, from: http://ojr.org/japan/wireless/1080854640.php

Mellow, P. (2005), “The Media Generation: Maximize Learning by Getting Mobile”, Proceedings of ASCILITE 2005. Retrieved January 12, 2010, from

http://www.ascilite.org.au/conferences/brisbane05/proceedings.shtml.

Mitchell, A., Heppel, S., \& Kadirire, J. (2002). Technology Watch Research Report. Anglia: UltraLab.

Nation, I. S. P. (2001). Learning Vocabulary in Another Language, Cambridge: Cambridge University Press.

Norbrook, H., \& Scott, P. (2003). Motivation in Mobile Modern Foreign Language Learning, (5051), (Ed: J. Attewell, G. Da Bormida, M. Sharples, \& C. Savill-Smith), MLEARN 2003: Learning with Mobile Devices, London: Learning and Skills Development Agency.

Perlman, D. (2005). Drexel gives iPod photos to education grads. Retrieved December 13, 2005, from

http://www.dailypennsylvanian.com/vnews/display.v/ART/2005/03/04/42283c0b2ed6e.

Plant, S. (2001). On the Mobile - the effects of mobile telephones on individual and social life, Motorola. $\quad$ Retrieved October $14, \quad 2009$ from http://web.archive.org/web/20070127165250/http://www.motorola.com/mot/doc/0/267_MotDo c.pdf

Savill-Smith, C., \& Kent, P. (2003). The Use of Palmtop Computers for Learning: A Review of the Literature. London, UK: Learning and Skills Development Agency.

Sharples, M., Arnedillo-Sánchez, I., Milrad, M.\&Vavoula, G. (2006). Mobile Learning: Small Devices, Big Issues, (233-250), (Ed: S. Ludvigsen, N. Balacheff, T. de Jong, A. Lazonder, and S. 
Barnes), Technology-enhanced Learning: Principles and Products, Dordrecht: Springer.

Shudong, W. \& Higgins, M. (2005), "Limitations of mobile Phone Learning", Proceedings of the 2005 IEEE International Workshop on Wireless and Mobile Technologies in Education (WMTE'05), November 28-30,Tokushima, Japan.

Singh, G., Denoue, L., \& Das, A. (2004), "Collaborative Note Taking", Proceedings of the 2nd IEEE Workshop on Wireless and Mobile Technologies in Education (WMTE '04) (pp. 163-167), JungLi, Taiwan: IEEE Computer Society.

So, S. (2009). "The Development of a SMS-based Teaching and Learning System" Journal of Educational Technology Development and Exchange, 2-1, (113-124).

Sotillo, S.M. (2003). "Pedagogical Advantages of Ubiquitous Computing in a

Wireless Environment" The Technology Source, Retrieved June 16, 2010, from

http://education.korea.ac.kr/innwoo/edu603/Wireless/Pedagogical\%20Advantage

s\%20of\%20Ubiquitous\%20Computing\%20in\%20a\%20Wireless\%20Environment.htm.

Squire, K., Johnson, K., Holland, W., Nataf, Z., \& Klopfer, E. (2002). MIT Games-To-Teach. Design Document for: A Platform For Augmented Reality Gaming. Environmental Detectives. Retrieved March 15, 2008, from

http://cms.mit.edu/games/education/documents/Handheld/Handheld.doc.

Stockwell, G. (2007b). "Vocabulary on the Move: Investigating an Intelligent Mobile Phonedbased Vocabulary Tutor" Computer Assisted Language Learning, 20, (365-383).

Thornton, P. \& Houser, C. (2001), “Learning on the Move: Foreign Language Vocabulary via SMS", ED-Media 2001 Proceedings, pp. 1846-1847. Norfolk, Virginia: Association for the Advancement of Computing in Education.

Thornton, P., \& Houser, C. (2002). M-learning: Learning in Transit, (229-243), (Ed: P. Lewis), The Changing Face of CALL: A Japanese Perspective, Lisse, The Netherlands: Swets \& Zeitlinger.

Thornton, P. \& Houser, C. (2005). “Using Mobile Phones in English Education in Japan” Journal of Computer Assisted Learning, 21, (217-228).

Traxler, J. (2005). “Defining Mobile Learning", Proceedings IADIS International Conference Mobile Learning, Malta.

Trifonova, A. \& Ronchetti, M. (2003), “Where is Mobile Learning Going?” Proceedings of World Conference on E-Learning in Corporate, Government, Healthcare, and Higher Education 2003, 1794-1801, Chesapeake, VA: AACE. Retrieved from November 23, 2010 from http://citeseerx.ist.psu.edu/viewdoc/download?doi=10.1.1.57.9615\&rep=rep1\&type=pdf

Trifanova, A., Knapp, J., Ronchetti, M., \& Gamper, J. (2004). Mobile ELDIT: Challenges in the 
Transitions from an E-learning to an M-learning System (Technical Report \# DIT-04-009). Trento, Italy: University of Trento. Accessed 27th August 2010 from: http://eprints.biblio.unitn.it/archive/00000532/01/paper4911.pdf

Wagner, E.D. (2005). “Enabling Mobile Learning” EDUCAUSE Review, 40-3, (40-53).

\section{APPENDIX A}

\section{PRETEST}

Please write the Turkish meanings of the words below.

1. conjugation :

2. recover:

3. pique :

4. sapid :

5. granulate :

6. voracious :

7. specialize :

8. excretion :

9. plutocracy :

10. wantonness :

11. prurient:

12. illuminate :

13. awry :

14. counter-claim :

15. peter :

16. ambulance :

17. inundation :

18. imminence :

19. lough :

20. discolor : 
APPENDIX B

POSTTEST

Please write the Turkish meanings of the words below.

Peter:

Sapid:

Awry:

Granulate:

Pique:

Wantonness:

Voracious:

Discolor:

Inundation:

Excretion: 


\section{APPENDIX C}

\section{Student Attitude Questionnaire Towards SMS System}

Indicate how much you agree or disagree from the following choices.

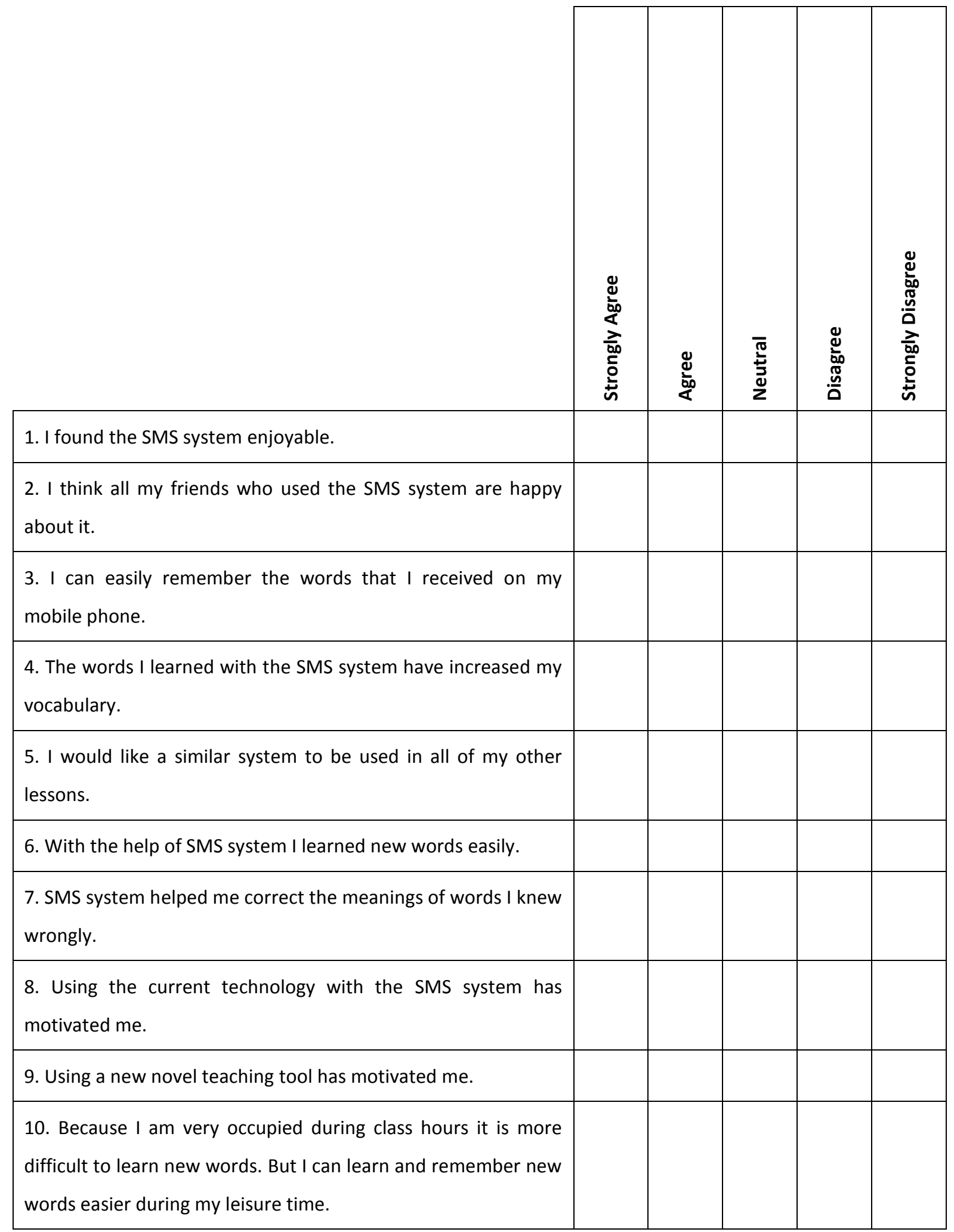




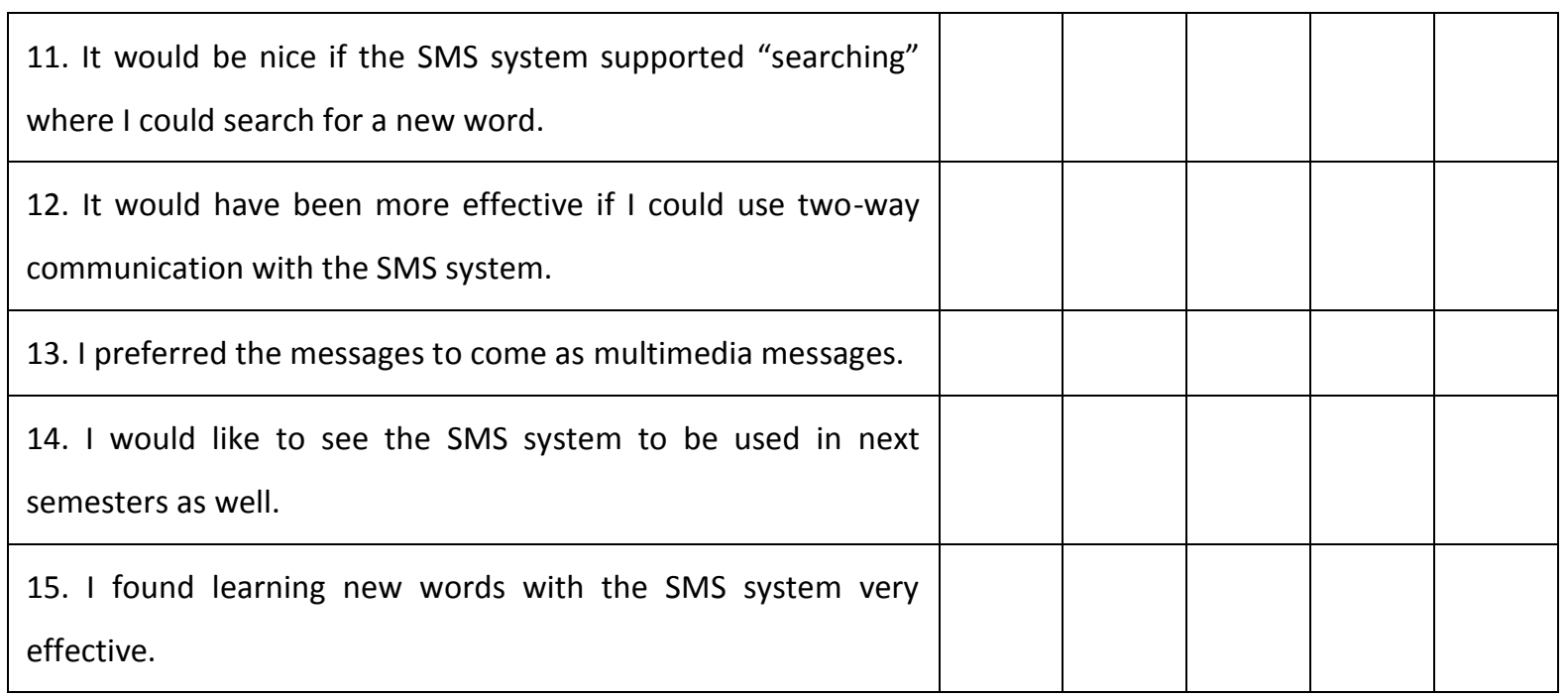

